\title{
COMMENTS
}

\section{DISPOSITION OF MOOT CASES BY THE UNITED STATES SUPREME COURT}

The usual manner in which the United States Supreme Court disposes of cases moot upon appeal has been succinctly stated:

When it is shown that a case brought from a lower federal court has become moot, the Supreme Court, under the present practice, usually reverses or vacates the judgment or decree and remands with directions to dismiss the bill, complaint or petition. ... If the proceeding is one to review the decision of a state court, and the cause is shown to have become moot since the entry of the judgment or decree of the highest state court and pending decision by the Supreme Court, the Supreme Court remands the cause to the state court in order that that court may take such further proceedings as may be deemed appropriate. ${ }^{1}$

The Supreme Court's practice of eliminating all lower proceedings in federal moot cases may surprise the average lawyer. ${ }^{2}$ Reversal or vacation has even

\footnotetext{
${ }^{1}$ Robertson \& Kirkham, Jurisdiction of the Supreme Court of the United States $\$ 273$ (Wolfson and Kurland's ed., 1951).

The boundaries of mootness are not clearly defined. A generally quoted judicial definition of a moot case is: "[A] moot case is one which seeks to get a judgment on a pretended controversy, when in reality there is none, or a decision in advance about a right before it has been actually asserted and contested, or a judgment upon some matter which, when rendered, for any reason, cannot have any practical effect upon a then existing controversy." Ex parte Steele, 162 Fed. 694, 701 (N.D. Ala., 1908).

Abatement is distinguished from mootness by the fact that in abatement the suit terminates solely because of want of proper parties capable of proceeding therein. Consult Bouvier, Law Dictionary 6. Cases dismissed as abated, though closely related to moot appeals in the end result, are not included in this note. Consult Richardson v. McChesney, 218 U.S. $487,492-3$ (1910), illustrating the similarity of the doctrines.

The question of what constitutes a moot case is not within the scope of this comment. Every case which the Supreme Court has held to be moot (together with the lower decisions when reported) has been read and indication will be made as to why each case was declared to be moot (cases cited notes 8-17 infra). For an excellent discussion of federal mootness doctrines and cases consult Diamond, Federal Jurisdiction to Decide Moot Cases, $94 \mathrm{U}$. of Pa. L. Rev. 125 (1946). Other discussions may be found in: Robertson \& Kirkham, Jurisdiction of the Supreme Court of the United States, c. 36 (Wolfson and Kurland's ed., 1951) ; Cases Moot Upon Appeal: A Limit on the Judicial Power, 103 U. of Pa. L. Rev. 772 (1955); Administrative Law: Questions "Moot" on Appeal, 22 Ind. L. J. 235 (1947); "Moot" Administrative Orders, 53 Harv. L. Rev. 628 (1940).

-See Table 1. Illinois in contrast to the Supreme Court has retained the practice of dismissing moot appeals. See, e.g., People ex rel. Wallace v. Labrenz, 411 III. 618, 104 N.E. 2d 769 (1952), cert. denied 344 U.S. 824 (1952); Barnard v. Michael, 392 Ill. 130, 63 N.E. 2d 858 (1945); First National Bank of Jonesboro v. Road Dist. No. 8, 389 III. 156, 58 N.E. 2d 884 (1945); People ex rel. Cassidy v. Fisher, 372 Ill. 146, 22 N.E. 2d 937 (1939). Only
} 
been stated by the Supreme Court to be the "duty" of the circuit court of appeals. ${ }^{3}$ (The Court did not say whether this "duty" to vacate applied to every moot appeal or only those where the appellant requested vacation.) ${ }^{4}$ Frequently overlooked is the fact that for much the greater part of its history the Supreme Court's customary procedure was to dismiss in moot cases appeals from both the federal and the state courts.

A decree in a case moot on appeal by definition cannot directly effect any change in the legal rights of the parties to the action. The main interest, therefore, in the disposition of moot appeals arises from a consideration of the effects the original adversary decree may have upon the same parties in future actions, and what weight ought to be accorded the adversary decree in litigation involving other parties. The first problem concerns res judicata, and the second, stare decisis. The manner of disposition is primarily important, since only if the moot appeal is dismissed is there an existing lower judgment from which res judicata effects could flow. Stare decisis would theoretically operate independently of the manner of disposition chosen, but the Supreme Court possibly could show displeasure with the lower decree by reversing or vacating it.

This comment first undertakes to demonstrate the change in the general manner of disposition and to determine to what extent the changes have been conscious and motivated by considerations of justice or reason. All cases held by the Supreme Court to be moot, either at their inception or on appeal, have been investigated and classified. ${ }^{5}$ The res judicata and stare decisis effects of judgments moot on appeal will then be examined.

where good cause can be shown will an Illinois appellate court reverse or vacate a judgment which has become moot on appeal. E.g., People v. Redlich, 402 IIl. 270, 83 N.E. 2d 736 (1949). Redlich had been ordered by the court to submit to a psychiatric examination to determine whether or not he should be prosecuted as a normal person. Redlich refused to submit, and was sentenced for contempt. The appeal was from this contempt sentence. Before the Illinois Supreme Court heard the appeal, Redlich was prosecuted under his original indictment and convicted, thus mooting the contempt appeal. Since Redlich would remain in prison indefinitely under the contempt sentence otherwise, the court reversed that sentence.

${ }^{3}$ See Duke Power Company v. Greenwood County, 299 U.S. 259, 267 (1936). Cited with approval in United States v. Munsingwear, Inc., 340 U.S. 36, 39-40 (1950). The Supreme Court has never said that such a "duty" applies to itself. Consult note 18 infra.

'See United States v. Munsingwear, Inc., 340 U.S. 36, 39-40 (1950). Consult note 38 infra.

5 There has been some discussion as to whether the Supreme Court in speaking of the lack of the "case" or "controversy" element in a moot case is referring to the common law requirement for a justiciable controversy or to the Article III jurisdictional requirement of the federal Constitution. It is generally agreed that this lack is a self-imposed common law judicial limitation on jurisdiction based upon convenience and necessity. Consult Robertson \& Kirkham, Jurisdiction of the Supreme Court of the United States $\$ 270$ (Wolfson and Kurland's ed., 1951) ; "Moot" Administrative Orders, 53 Harv. L. Rev. 628, 629 (1940). Therefore the many cases which show a failure to comply with the Article 
The Supreme Court at some time-undeterminable precisely-after the turn of the present century changed the general manner of disposition of moot appeals from federal and state decisions from dismissal of the appeal to a disposition which eliminated the entire proceeding. Because the Court assumed in Board of Public Utility Commissioners v. Compania General de Tabacos, ${ }^{6}$ in 1919 , that the "proper course ... as is shown by many precedents, [was] to reverse the judgment and remand the cause with a direction that it be dismissed without costs to either party," the year 1919 and the Compania General case will arbitrarily be taken as the dividing line. This is the first decision in which the Supreme Court assumes that the disposition is established. Table 1 shows the change in the manner of disposition used in terms of pre-1919 and post-1919.

\section{TABLE 1}

Cases from the federal system:

$$
\text { Pre-1919 Post-1919 }
$$

Judgment reversed or vacated and cause remanded with directions to dismiss the complaint $\ldots \ldots \ldots \ldots \ldots \ldots, 9^{8}$

Appeal dismissed $\ldots \ldots \ldots \ldots \ldots \ldots 23^{10}$

$37^{9}$

Erratic disposition $\ldots \ldots \ldots \ldots \ldots \ldots, 2^{12}$

Cases from the state courts:

Judgment reversed or vacated and cause remanded for appropriate proceedings $1^{14} \quad 6^{15}$ Appeal dismissed $\ldots \ldots \ldots \ldots \ldots \ldots \ldots \ldots \ldots 1^{10} \quad 2^{17}$

III requirement of "case" and "controversy" and which do not concern common law mootness are not included within this note as they sometimes are in discussions of cases moot on appeal. Consult Cases Moot On Appeal: A Limit on the Judicial Power, $103 \mathrm{U}$. of Pa. L. Rev. 772, 776 (1955), discussing Muskrat v. United States, 219 U.S. 346 (1911).

- 249 U.S. 425 (1919) (Amendment abrogated the provision in Philippine act which court below held to be undue delegation of legislative power).

I Tbid., at 426-27.

${ }^{8} \mathrm{Judgment}$ below reversed (or vacated) and remanded with instructions to dismiss or take appropriate action: Berry v. Davis, 242 U.S. 468 (1917) (injunction granted below on basis of statute which had since been amended to exclude plaintiff); United States v. American-Asiatic S.S. Co., 242 U.S. 537 (1917) (alleged anti-trust activity terminated by war) ; United States v. Hamburg-Amerikanische Packetfahrt-Action Gesellschaft, 239 U.S. 466 (1916) (alleged antitrust activity terminated by war); Metzger Motor Car Co. v. Parrott, 233 U.S. 36 (1914) (statutory cause of action abolished pending appellate decision); New Orleans Flour Inspectors v. Glover, 161 U.S. 101 (1896) (disputed statute had been repealed) ; South Spring Gold Co. v. Amador Gold Co., 145 U.S. 300 (1892) (reversed and remanded for further proceedings. A third party had purchased control of both adversaries) ; Meyer v. Pritchard, 131 U.S. ccix Appx. (1877) (the disputed patent was surrendered pending appeal); Gardner v. Goodyear Dental Vulcanite Co., 131 U.S. ciii Appx. (1873) (suit discovered to be collusive, Supreme Court vacated its previous judgment); Lord v. Veazie, 8 How. (U.S.) 250 (1850) ("Writ of error dismissed and cause remanded to be dealt with according to instructions.") (collusive suit discovered). 
${ }^{2}$ Judgment below reversed (or vacated) and remanded with instructions to dismiss or take appropriate action: Alton v. Alton, 347 U.S. 610 (1954) (relief requested had since been granted); Gray v. U. of Tennessee, 342 U.S. 517 (1952) relief requested had since been granted); SEC v. Harrison, 340 U.S. 908 (1951) (cause of mootness unreported); Howard v. United States, 340 U.S. 898 (1950) (acquiescence of one party) ; SEC v. Philadelphia Co., 337 U.S. 901 (1949) (settlement); Hodge v. Tulsa County Election Board, 335 U.S. 889 (1948) (cause of mootness not reported; probably passage of time made relief requested ineffectual); SEC v. Engineers Public Service Co., 332 U.S. 788 (1947) (settlement) ; Farmers Grain Co. v. Brotherhood of Locomotive Firemen \& Enginemen, 332 U.S. 748 (1947) (settlement); Montgomery Ward \& Co. v. United States, 326 U.S. 690 (1945) (cause of mootness unreported); SEC v. Long Island Lighting Co., 325 U.S. 833 (1945) (premature controversy); United States v. Johnson, 319 U.S. 302 (1943) (collusive suit); Agricultural Prorate Commission v. Mutual Orange Distributors, 318 U.S. 744 (1943) (cause of mootness unreported) ; Stewart v. Southern Ry. Co., 315 U.S. 784 (1941) (settlement); Retail Food Clerks \& Mgrs. Union v. Union Premier Food Stores, Inc., 308 U.S. 526 (1940) (questions of law had been answered in prior hearing on supersedeas); Woodring v. Clarksburg-Columbus Short Route Bridge Co., 302 U.S. 658 (1937) (cause of mootness unreported); Leader v. Apex Hosiery Co., 302 U.S. 656 (1937) (cause of mootness unreported; probably injunctive relief had become ineffectual); Bracken v. SEC, 299 U.S. 504 (1936) (acquiescence by one party) ; Hammond Clock Co. v. Schiff, 293 U.S. 529 (1934) (settlement); O'Ryan v. Mills Novelty Co., 292 U.S. 609 (1934) (passage of statute made dispute moot); Danciger Oil \& Rfg. Co. v. Smith, 290 U.S. 599 (1933) (parties stipulate cause moot, reason unreported) ; First Union Trust \& Savings Bank v. Consumers Coal, 290 U.S. 585 (1933) (cause of mootness unreported); Coyne v. Prouty, 289 U.S. 704 (1932) (disputed statute repealed) ; Railroad Commission v. Macmillan, 287 U.S. 576 (1932) (disputed statute repealed); Mahan v. Hume, 287 U.S. 575 (1932) (lower decision granting injunction reversed because Supreme Court had since held that injunction was improper in that area); Hargis v. Bradford, 283 U.S. 781 (1931) (intervening law change, exact nature unreported) ; Sprunt \& Son, Inc. v. United States, 281 U.S. 249 (1930) (acquiescence in judgment in prior suit); United States v. Anchor Coal Co., 279 U.S. 812 (1929) (apparently the disputed ICC order was rescinded); Willing v. Chicago Auditorium Ass'n, 277 U.S. 274 (1928) (premature controversy); United States ex rel. Norwegian Nitrogen Products Co. v. United States Tariff Commission, 274 U.S. 106 (1927) (change in law making requested relief ineffectual); Alejandrino v. Quezon, 271 U.S. 528 (1926) (disputed suspension had expired); Brownlow v. Schwartz, 261 U.S. 216 (1923) (relief requested had been granted); Atherton Mills v. Johnston, 259 U.S. 13 (1922) (party had become too old to qualify as child laborer); Heitmuller v. Stokes, 256 U.S. 359 (1921) (one party sold his interest to a third party); United States v. Alaska S.S. Co., 253 U.S. 113 (1920) (disputed statute repealed) ; Commercial Cable Co. v. Burleson, 250 U.S. 360 (1919) (alleged wrongful actions had been terminated); Public Utility Commissioners v. Compania General de Tabacos, 249 U.S. 425 (1919) (disputed statute had been amended).

${ }^{10}$ Appeal, or writ of certiorari or error dismissed: Director of Prisons v. Court of First Instances, 239 U.S. 633 (1915) (convicts had been executed prior to hearing on denial of stay of execution); Stearns v. Wood, 236 U.S. 75 (1915) (plaintiff lacked legal interest to bring suit); Buck's Stove \& Range Co. v. AFL, 219 U.S. 581 (1911) (settlement); United States v. Evans, 213 U.S. 297 (1909) (criminal acquittal cannot be appealed, no Iegal question on appeal); Fisher v. Baker, 203 U.S. 174 (1906) (disputed suspension of habeas corpus had been revoked); Jones v. Montague, 194 U.S. 147 (1904) (acts sought to be prohibited had been accomplished); Ex parte Baez, 177 U.S. 378 (1900) (sentence had already been served); Mills v. Green, 159 U.S. 651 (1895) (payment of disputed tax pending appeal) ; California v. San Pablo \& Tulare R. Co., 149 U.S. 308 (1893) (payment of disputed tax pending appeal); Singer Mfg. Co. v. Wright, 141 U.S. 696 (1891) (payment of disputed tax pending appeal); Washington Market Co. v. Dist. of Columbia, 137 U.S. 62 (1890) (relief granted through another action); E. Tenn. R. Co. v. Southern Telegraph Co., 125 U.S. 695 (1888) (one party acquired legal interest of other); Addington v. Burke, 125 U.S. 693 (1887) (settlement); San Mateo County v. Southern Pacific R. Co., 116 U.S. 138 (1885) (disputed payment had been made); Dakota County v. Glidden, 113 U.S. 222 
No particular disposition has ever been used exclusively. The Court has said that it is free to make any disposition of a case which "justice may require."18 However, it is certain that the Supreme Court prior to 1919, with

(1885) (settlement); Cheong Ah Moy v. United States, 113 U.S. 216 (1885) (plaintiff had left territorial jurisdiction of the Supreme Court); Williams v. Hagood, 98 U.S. 72 (1878) (abstract question) ; Wood-Paper Co. v. Heft, 8 Wall. (U.S.) 333 (1869) (defendant purchased plaintiff's interest) ; United States v. Morillo, 1 Wall. (U.S.) 706 (1863) (lack of legal interest by one party); Cleveland v. Chamberlain, 1 Black (U.S.) 419 (1861) (one party equitably owns both interests) ; United States v. Chetimachas Indians, 131 U.S. Ixx Appx. (1852) (settlement); Cartwright v. Howe, 1 How. (U.S.) 188 (1843) (settlement).

"I Appeal, or writ of certiorari or error dismissed: Schenley Distilling Corp. v. Anderson, 333 U.S. 878 (1948) (parties agree cause is moot, reason not shown); Pan American Airways Corp. v. Grace \& Co., 332 U.S. 827 (1947) (reason not reported, probably settlement); Uyeki v. Styer, 329 U.S. 689 (1947) (reason for mootness unreported) ; Cantos v. Styer, 329 U.S. 686 (1946) (reason for mootness unreported) ; St. Pierre v. United States, 319 U.S. 41 (1943) (sentence had been served); Texas Consolidated Theaters v. Pittman, 305 U.S. 3 (1938) (settlement).

${ }^{12}$ Lewis Publishing Co. v. Wyman, 228 U.S. 610 (1913) (affirmed lower decree which had dismissed case as moot; relief requested had been granted); Dinsmore v. Southern Express Co., 183 U.S. 115 (1901) (lower decree affirmed because it dismissed the bill, which the Supreme Court would have done because of mootness. Statute had been amended so as to exclude plaintiffs).

${ }^{13}$ Eisler v. United States, 338 U.S. 189 (1949) (review postponed indefinitely when Eisler jumped bail and fled the country); Royal Cadillac Service, Inc. v. United States, 317 U.S. 595 (1942) (judgment which denied temporary relief affirmed because permanent relief had since been denied by ICC); Barker Co. v. Painters Union, 281 U.S. 462 (1930) (circuit court of appeals' decree affirmed which had dismissed the bill because of mootness, disputed act having been completed).

" Gulf C. \& S.F. Ry. Co. v. Dennis, 224 U.S. 503 (1912) (reversed and "remanded for further proceedings not inconsistent with this opinion." Statutory cause of action abolished).

${ }^{15}$ Reversed (or vacated) and remanded for further proceedings in conformity with the decision: Harris v. Battle, 348 U.S. 803 (1954) (protested action had ceased) ; Amalgamated Ass'n S.E.R. \& M.C.E. of A. v. Wisconsin Employment Relations Board, 340 U.S. 416 (1951) (companion case decision had forced reversal of this case); Riley v. International Brotherhood of T., C., W. \& H. of A., 336 U.S. 930 (1949) (reason for mootness unreported); Dyer v. City Council of Beloit, 333 U.S. 825 (1948) (acquiescence); Natural Milk Producers Ass'n v. San Francisco, 317 U.S. 423 (1943) (change in regulations made any relief impossible); Washington ex rel. Columbia Broadcasting Co. v. Superior Court of the State of Washington for King County, 310 U.S. 613 (1940) (reason for mootness unreported).

${ }^{16}$ Appeal dismissed: Richardson v. McChesney, 218 U.S. 487 (1910) (acts sought to be prevented have been done); Security Mutual Life Insurance Co. v. Prewitt, 200 U.S. 446 (1906) (passage of time had made requested relief impossible); Travelers Insurance Co. v. Prewitt, 200 U.S. 450 (1906) (passage of time had made requested relief impossible); American Book Co. v. Kansas, 193 U.S. 49 (1904) (disputed payment made pending appeal); Tennessee v. Condon, 189 U.S. 64 (1903) (terms of disputed office had expired); Codlin v. Kohlhausen, 181 U.S. 151 (1901) (act sought to be prohibited had been done); Tyler v. Judges of the Court of Registration, 179 U.S. 405 (1900) (plaintiff lacked sufficient legal interest) ; Kimball v. Kimball, 174 U.S. 158 (1899) (not "case" or "controversy" in federal sense) ; Little v. Bowers, 134 U.S. 547 (1890) (disputed payment made pending appeal); Peck v. Young, 1 How. (U.S.) 250 (1843) (settlement).

${ }^{17}$ Appeal dismissed: Chandler v. Wise, 307 U.S. 474 (1939) (act sought to be prohibited was accomplished) ; Allen \& Reed, Inc. v. Presbrey, 280 U.S. 518 (1929) (reason for mootness unreported, apparently settlement).

${ }^{28}$ Walling v. Reuter, Inc., 321 U.S. 671, 677 (1943). The government prosecuted Reuter, 
relatively few exceptions, dismissed the appeal when the case had become moot, and that after 1919 the Court has just as definitely preferred, with little explication, to reverse or vacate the lower judgment and remand with instructions. The aberrations from the general manner of disposition in each of the two periods (pre-1919 and post-1919) in appeals from both state and federal courts (the un-italicized numbers in the chart) do suggest, however, that considerations of justice and not "rules" of disposition of moot cases are controlling where such considerations are germane.

Of the cases from the federal system, the nine pre-1919 appeals which were reversed or vacated and remanded with instructions ${ }^{19}$ were mostly cases where the dismissal of the appeal might well have worked an injustice. ${ }^{20}$ Collusive actions were reversed and the complaint dismissed, ${ }^{21}$ as were injunctions, when the appeals had become moot. ${ }^{22}$ When circumstances beyond either party's control made an antitrust case moot, judgments for the defendants were vacated, ${ }^{23}$ and where either disposition would prejudice one or the other party to an action, the Court remanded with appropriate instructions. ${ }^{24}$ On the other hand, examination of the cases did not show any reason why the six post-1919

Inc., a family corporation, for a wage and hour violation and obtained an injunction against the officers and managers. Walling v. Reuter, Inc., 49 F. Supp. 485 (E.D. La., 1943). Pending appeal to the circuit court of appeals the corporation was dissolved. Reuter pleaded that the proceeding was moot and that the proper procedure was to reverse and dismiss. The circuit court of appeals reversed on this ground. Reuter, Inc. v. Walling, 137 F. 2d 315 (C.A. 5th, 1943). On appeal the Supreme Court reinstated the injunction as against the individuals originally named and remanded the case to the district court for further proceedings as if no appeal had ever been taken from the trial decree. The Supreme Court was undoubtedly influenced by the fact that the individuals had begun again the same operations previously carried on by Reuter, Inc.

${ }^{19}$ Cases cited note 8 supra.

${ }^{20}$ Meyer v. Pritchard, 131 U.S. ccix Appx. (1873), is the only case cited in note 8 which does not present good reason to eliminate the lower judgment. The appellant was the original plaintiff and judgment had been for the defendant. The mootness was caused solely (though unwittingly) by the plaintiff-appellant.

${ }^{21}$ Gardner v. Goodyear Dental Vulcanite Co., 131 U.S. ciii Appx. (1873) ; Lord v. Veazie, 8 How. (U.S.) 251 (1850).

${ }^{22}$ Berry v. Davis, 242 U.S. 468 (1917) (lower court had erroneously taken jurisdiction when action was moot, Davis v. Berry, 216 Fed. 413 [S.D. Jowa, 1914]); New Orleans Flour Inspectors v. Glover, 161 U.S. 101 (1896).

${ }^{2}$ United States v. American-Asiatic S.S. Co., 242 U.S. 537 (1917); United States v. Hamburg-Amerikanische Packetfahrt-Actien Gesellschaft, 239 U.S. 466 (1915). The suits were terminated by the necessary cessation of alleged illegal activities.

${ }^{2}$ South Spring Gold Co. v. Amador Gold Co., 145 U.S. 300 (1892). The control of the disputing corporations had passed since trial into the hands of a third party. The two corporations were still existent and organized; and the new managers of the corporations wished the Court to adjudicate the plaintiff's claim for the benefit of the plaintiff's minority stockholders. The appeal being moot, the Court could not adjudicate the claim, but reversal would injure the plaintiff's minority stockholders since the plaintiff had recovered judgment below. Dismissal of the appeal would likewise prejudice the managers. Thus the Court vacated and remanded with instructions to allow a new trial. 
federal cases disposed of by dismissing the appea ${ }^{25}$ were not reversed or vacated according to the general rule recognized in 1919.

Gulf Colorado \& Santa Fe Ry. Co. v. Dennis, ${ }^{26}$ the only pre-1919 state case in which the lower decision was reversed and remanded, was so disposed of because the statute on which the judgment for the plaintiff had been rendered had since been declared unconstitutional. Analysis of the two post-1919 state cases in which the appeals were dismissed ${ }^{27}$ instead of the judgments vacated and remanded reveals no reason for this variation in disposition (as with the federal cases similarly treated).

That there may be exceptions to every rule as the demands of justice require does not of course explain why the general manner of disposition of moot appeals has changed. As previously stated, there seems to be no explicit single reason for the change. The twenty-three pre-1919 federal cases in which the appeal was dismissed ${ }^{28}$ seem to have been satisfactorily handled, at least only in one instance were adverse consequences discovered. ${ }^{29}$ The only explanation which has been offered to rationalize the present practice of eliminating the lower judgment is the desire to preclude possible unjust unforeseen effects, ${ }^{30}$ and collateral estoppel. ${ }^{31}$ It had been generally thought, however, that no collateral estoppel would flow from a decree moot on appeal. ${ }^{32}$

The generally accepted position refusing collateral estoppel effects in a judgment moot on appeal was qualified at least insofar as the federal courts are concerned by United States $v$. Munsingwear, Inc..$^{33}$ In the Munsingwear case, the government filed two actions against Munsingwear, a suit for an injunction and a treble damage action, both suits based upon alleged violations of

${ }^{25}$ Cases cited note 11 supra.

224 U.S. 503 (1912).
${ }^{27}$ Cases cited note 17 supra.

${ }^{28}$ Cases cited note 10 supra.

${ }^{2}$ New Orleans Flour Inspectors v. Glover, 160 U.S. 170 (1895), is the one exception. Louisiana passed an act for the inspection of all flour entering the port of New Orleans. Glover obtained an injunction prohibiting enforcement of the act. Pending the appeal to the Supreme Court the disputed act was repealed, mooting the appeal. The Supreme Court dismissed the appeal. One year later the Supreme Court vacated its disposition and reversed and dismissed the original injunction, because the language of the injunction which had been left in force was so broad as to hamper the inspectors in their normal duties. New Orleans Flour Inspectors v. Glover, 161 U.S. 101 (1896).

${ }^{30}$ See, e.g., New Orleans Flour case discussed in note 29 supra.

sr Consult United States v. Munsingwear, Inc., 340 U.S. 36 (1950); Stern \& Gressman, Supreme Court Practice 342 (1950 ed.); Cases Moot On Appeal: A Limit on the Judicial Power, 103 U. of Pa. L. Rev. 772, 794 (1955).

${ }^{32}$ Restatement of Judgments, $\$ 69(2)$ (1942 ed.). See also Scott, Collateral Estoppel by Judgment, 56 Harv. L. Rev. 1, 15-16 (1942). Recently, however, Mr. Justice Schaefer speaking for the Illinois Supreme Court stated that "the effect, as res judicata of a judgment which could not be reviewed because intervening circumstances made the case moot, has not been settled in this State." People ex rel. Wallace v. Labrenz, 411 III. 618, 623, 104 N.E. 2d 769, 772-73 (1952), cert. denied 344 U.S. 824 (1952).

\$3 340 U.S. 36 (1950). 
the same OPA ceiling price regulations. The actions were split by agreement, that for injunctive relief being tried first and denied on the merits by the trial court. ${ }^{34}$ Pending appeal to the circuit court of appeals, the articles in question were decontrolled, and the appeal was dismissed as moot. ${ }^{35}$ Munsingwear then moved in the district court to dismiss the treble damage action on the ground that the unreversed judgment of the district court in the injunction proceeding collaterally estopped the prosecution of the damage actions. This motion was granted and affirmed on appeal by the circuit court of appeals. ${ }^{30}$ The Supreme Court affirmed stating that if the government had not wished to be collaterally estopped to relitigate the question of the alleged violations of the rgulations, it should have requested reversal and dismissal of the injunction proceeding when the circuit court of appeals held that the appeal was moot. Denial of the petition to reverse would have been grounds for appeal to the Supreme Court. ${ }^{37}$

Under the doctrine of the Munsingwear case the circuit courts have a "duty" to reverse or vacate the district court judgment when moot on appeal, at least if requested by the appellant. ${ }^{38}$ The circuit courts have apparently resolved any ambiguity by reversing in all moot appeals. ${ }^{39}$ Nothing definite,

\footnotetext{
${ }^{34}$ Bowles v. Munsingwear, Inc., 63 F. Supp. 933 (D. Minn., 1945).

${ }^{35}$ Fleming v. Munsingwear, Inc., 162 F. 2d 125 (C.A. 8th, 1947).

${ }^{38}$ United States v. Munsingwear, 178 F. 2d 204 (C.A. 8th, 1949).
}

${ }^{37}$ United States v. Munsingwear, Inc., 340 U.S. 36, 40 (1950). Although the Supreme Court undoubtedly placed its decision in the Munsingwear case on procedural "acquiescence" by the government, it is submitted that another consideration was also present, a desire by the Supreme Court to force a complete review of actions held to be moot. Commentators have overlooked the importance of the particular controversy. An administrative order was the basis of the prosecutions, and its revocation caused the mootness. Yet the Supreme Court might not have upheld the circuit court of appeals' decision that the injunction proceeding was moot (although there is no language to indicate this). Where short term administrative orders are contested, their revocation does not necessarily moot any proceeding brought under them. Southern Pacific Terminal Co. v. ICC, 219 U.S. 498 (1911). In the Munsingwear case the proper course for the United States would have been to contest the disposition in the decision of mootness by the circuit court of appeals through appeal to the Supreme Court. If the circuit court of appeals had originally vacated and dismissed the injunction proceeding, Munsingwear could have appealed the merits of the finding of mootness in an attempt to protect the judgment of the district court rendered in their favor. In either situation the Supreme Court would have had to pass on the validity of the finding of mootness.

The Munsingwear doctrine has given rise to both favorable and unfavorable commentunfavorable: 30 B. U. L. Rev. 426 (1950); 50 Col. L. Rev. 716 (1950); 26 N. D. Bar Briefs 423 (1950); favorable: 48 Mich. L. Rev. 1208 (1950); 35 Minn. L. Rev. 506 (1951); 7 Wash. \& Lee L. Rev. 230 (1950).

${ }^{33}$ United States v. Munsingwear, Inc., 340 U.S. 36, 40 (1950). The "duty" to reverse or vacate is not clearly defined by the Supreme Court. It might be the duty of the circuit courts to reverse and vacate only if requested, or in all moot appeals even if no request has been made. A third possibility, unlikely in view of the language of the case, would require that a strong showing of possible prejudice be made. Consult note 39 infra.

29 Three cases moot on appeal to the circuit courts have since been disposed of on the authority of the Munsingwear case: Kelaghan v. Industrial Trust Co., 211 F. 2d 134 (C.A. 1st, 1954) (order of vacation and dismissal without prejudice despite defendant-appellee's 
however, has been said about the collateral estoppel effects of judgments which become moot on appeal to the Supreme Court.

Theoretically, there exist at least five possibilities as to alternative modes of disposition by the Supreme Court and attendant collateral estoppel effects: 1. Collateral estoppel will not attach to any judgment moot upon appeal to the Supreme Court regardless of the disposition by that Court. Munsingwear did not deal with this situation, of course, but it seems most probable that the Supreme Court meant that collateral estoppel would attach to any judgment on the merits which became moot on appeal and was not reversed and dismissed as moot. The assumption that an unreversed judgment moot on appeal to the Supreme Court will give collateral estoppel effects introduces the remaining possibilities; 2. The Supreme Court will always reverse a moot appeal, without the necessity of motion from either party. This is unlikely because parties could not then stipulate to allow the judgment on the merits to stand; 3 . The Supreme Court will and must reverse a judgment moot on appeal if one party requests; 4 . The Supreme Court will ordinarily reverse a moot appeal if one party requests such disposition, but the Court will retain discretion to refuse such requests. Munsingwear seems to deny such discretion, at least to the circuit court, through reference to the "duty" to reverse when requested; 5 . The Supreme Court will reverse a moot appeal only if the petitioning party can show possible prejudice, such as the pending proceeding in Munsingwear. This seems very unlikely, in view of the consistent use of the prevailing mode of disposition.

stipulation that it would not use the prior judgment as res judicata in any future action which the plaintiff wished to bring); Hann v. Hawk, 205 F. 2d 839, 840 (C.A. 8th, 1953) ("Following the established practice in dealing with a case such as this which became moot pending a decision of this Court on the merits, the judgment appealed from is vacated and the case is remanded with directions to dismiss it." The Hann case was an appeal from a decision granting habeas corpus) ; Acheson v. Droesse, 197 F. 2d 574 (C.A. D.C., 1952) presents an interesting resolution of the ambiguous "duty." Droesse brought an action to cancel a Certificate of Loss of Nationality issued by the Secretary of State. Trial judgment went for Droesse on the pleadings. Pending appeal to the circuit court of appeals, Congress enacted a private law allowing Droesse to retain her citizenship, mooting the appeal. Droesse moved to dismiss the appeal on the ground that there could be no future litigation. The government requested vacation and dismissal on the authority of the Munsingwear case. The circuit court of appeals dismissed the appeal and then remanded the case to the district court with directions to vacate its judgment. "We think the language of the Supreme Court in the Munsingwear case clearly directs the Courts of Appeals that in all civil cases in the United States courts which became moot pending appeal, and in which a motion to dismiss as moot is accompanied by a motion to direct that the judgment below be vacated, both motions should be granted." Acheson v. Droesse, 197 F. 2d 574, 578 (C.A. D.C., 1952). The plaintiff in the Droesse case had been awarded the only decision on the merits, and the reason why the appeal became moot was compatible with the judgment; therefore the circuit court of appeals should have simply dismissed the appeal and allowed the lower judgment to stand in case the private law should be repealed. For further explanation of this position consult discussion of Alton v. Alton hypothetical case at page 89. Consult Dyer v. City Council of Beloit, 252 Wis. 249, 32 N.W.2d 333 (1948), to see how a state court might have handled a similar problem. 
Possibility three is the one most likely, as indicated by the lack of dismissal of any moot appeals since the Munsingwear case. ${ }^{40}$ (This record of unvarying reversals also preserves, of course, possibility two.) This position, however, could lead to serious injustice in some instances. (See discussion page 89 infra.) Possibilities four and five are less likely, but probably the more just. If the appellant cannot show a pending or probable proceeding which would be unjustly affected by the unreversed judgment moot on appeal, there is no reason why the judgment should not be allowed to stand so as to allow merger and bar effects. (See discussion page 93 infra.)

Examination of all the cases indicates a possible hidden reason for the general change in disposition. Insofar as the cases from the federal system are concerned, it is of interest that sixteen of the thirty-seven post-1919 cases which were reversed or vacated ${ }^{41}$ were suits to contest the validity of an executive or administrative ruling. No post-1919 federal cases in which the appeal was dismissed" ${ }^{42}$ concern the same type of action. The modern "general rule" as to the disposition of actions in the federal system and moot upon appeal to the Supreme Court is then about forty per-cent comprised of cases involving administrative and executive ruling contests where the disposition has been unvarying. It is conceivable that the Supreme Court has good reason for giving a disposition which eliminates the lower judgment in most appeals testing administrative rulings. Perhaps the rapidly changing nature of administrative law requires that all judgments moot on appeal be eliminated for stare decisis reasons. Since so many of the appeals concern just such questions, the Court may without conscious design have fallen into the use of such disposition in all of its moot appeals, whether the cases come from the state or federal system.

Although the administrative rulings cases may offer some explanation in addition to considerations of collateral estoppel and other "unforeseen effects" as to why the Supreme Court has changed its general manner of disposition in cases coming from the federal courts, there is no additional reason, other than .

${ }^{10}$ Consult notes 11,13 and 17 supra. It is impossible to determine whether there were requests for reversals in all cases since Munsingwear.

${ }^{4}$ SEC v. Harrison, 340 U.S. 908 (1951) ; SEC v. Philadelphia Co., 337 U.S. 901 (1949); SEC v. Engineers Public Service Co., 332 U.S. 788 (1947); Montgomery Ward \& Co. v. United States, 326 U.S. 690 (1945) ; SEC v. Long Island Lighting Co., 325 U.S. 833 (1945); Agricultural Prorate Commission v. Mutual Orange Distributors, 318 U.S. 744 (1943); Woodring v. Clarksburg-Columbus Short Route Bridge Co., 302 U.S. 658 (1937); Bracken v. SEC, 299 U.S. 504 (1936) ; Danciger Oil \& Rfg. Co. v. Smith, 290 U.S. 599 (1933) ; R.R. Commission v. Macmillan, 287 U.S. 576 (1932); Sprunt \& Son, Inc. v. United States, 281 U.S. 249 (1930) ; United States v. Anchor Coal Co., 279 U.S. 812 (1929); United States ex rel. Norwegian Nitrogen Products Co. v. United States Tariff Commission, 274 U.S. 106 (1927); Brownlow v. Schwartz, 261 U.S. 216 (1923) ; United States v. Alaska S.S. Co., 253 U.S. 113 (1920); Public Utility Commissioners v. Compania General de Tabacos, 249 U.S. 425 (1919).

2 Cases cited note 11 supra. 
habit formed in disposing of federal moot appeals, which would seem to explain the general change from simply dismissing the appeals in cases from the state courts.

Of the six post-1919 state cases disposed of by vacation, ${ }^{43}$ only two present definite reasons for the use of this mode of disposition. Amalgamated Ass'n S.E.R.EM.C.E. of A. v. Wisconsin Employment Relations Board ${ }^{44}$ was an appeal from a temporary award made on the basis of the Wisconsin Public Utilities Anti-Strike Statute. ${ }^{45}$ The case was one of two companion cases, in the other case an injunction having been granted on the basis of the same statute. On appeal, the injunction was reversed ${ }^{46}$ because the Supreme Court found that the Anti-Strike Statute was in conflict with the federal emergency labor relations provision of the Labor Management Relations Act as amended in 1947.47 It was necessary presumably to reverse the temporary award to prevent any collateral estoppel effects. ${ }^{48}$ In Dyer v. City Council of Beloit, ${ }^{49}$ the appellant had been denied a license to sell milk in the city of Beloit by the Wisconsin Supreme Court.50 Pending appeal, Dyer was granted his license, mooting his appeal. Dyer requested that the Wisconsin judgment be reversed so that after he had withdrawn his appeal the license could not be withdrawn on the basis of the unreversed Wisconsin judgment which denied Dyer's right to a license. The Supreme Court vacated the lower judgment and remanded the cause to the Wisconsin court for further proceedings. ${ }^{51}$ The Wisconsin court then reversed its own previous judgment and remanded the case for dismissal. ${ }^{52}$ Apparently when a judgment from a state court becomes moot on appeal to the Supreme Court and is vacated and remanded, it is proper to have a rehearing before the state supreme court. The state supreme court then decides whether to reverse or affirm its prior judgment. ${ }^{53}$

${ }^{23}$ Cases cited note 15 supra.

«30 U.S. 416 (1951).

${ }^{45}$ Wis. Stat. $\$ \$ 111.50-111.64$ (1953 ed.).

"Amalgamated Ass'n S.E.R. \& M.C.E. of A. v. Wisconsin Employment Relations Board, 340 U.S. 383 (1951).

${ }^{4}$ Labor Management Relations Act, 1947, $§ 206-10,61$ Stat. 155-56 (1947), 29 U.S.C. $\$ \$ 176-80$ (1952 ed.).

${ }^{48}$ Regarding the applicability of the Munsingwear doctrine to state cases see p. 95 .

4333 U.S. 825 (1948).

${ }^{50}$ Dyer v. City Council of Beloit, 250 Wis. 613, 27 N.W. 2d 733 (1947).

${ }^{5}$ Dyer v. City Council of Beloit, 333 U.S. 825 (1948).

${ }^{82}$ Dyer v. City Council of Beloit, 252 Wis. 249, 32 N.W. 2 d 333 (1948).

${ }^{53}$ Dyer v. City Council of Beloit, 250 Wis. 613, 27 N.W. 2d 733 (1947) (aff'd), 333 U.S. 825 (1948) (vacated and remanded), 252 Wis. 249,32 N.W. 2d 333 (1948) (Judgment appealed from reversed and cause remanded with directions to dismiss the complaint) ; Natural Milk Producers Ass'n v. San Francisco, 20 Cal. 2d 101, 124 P. 2d 25 (1942) (aff'd), 317 U.S. 423 (1943) (vacated and remanded), 24 Cal. 2d 122, 148 P. 2d 377 (1944) (because the plaintiffs advanced the same arguments as previously, the court affirmed the views expressed in its previous opinion); Washington ex rel. Columbia Broadcasting Co. v. Su- 
No apparent dissatisfaction had existed with the previous usual practice of dismissing appeals in cases from the state courts, Kimball v. Kimball ${ }^{54}$ being the only pre-1919 state case disposed of by dismissing the appeal ${ }^{55}$ which presented any problems in the choice of appropriate disposition. Mr. Kimball died, apparently intestate. This action was a suit brought by Kimball's alleged widow contesting the issuance of letters of administration to Kimball's mother and sister. The defense was that the alleged widow had never been legally divorced from a prior husband. (The alleged widow had left her New York City home and gone to North Dakota, where after a three months' residence she had obtained a default decree of divorce from her first husband. The widow immediately returned to New York City and six months later went through a marriage ceremony with Kimball.)

The New York Court of Appeals held that the alleged widow was not entitled to the letters of administration because she had not been legally divorced. ${ }^{56}$ Writ of error was taken to the Supreme Court, but before hearing there it was learned that some time previous to the New York Court of Appeals hearing a will had been found and admitted to probate, thus mooting the administration contest. Fearing that the New York Court of Appeals decision would collaterally estop her in a will contest, the alleged widow requested that the moot appeal be reversed and the action dismissed. The Supreme Court noted this but refused the request and simply dismissed the writ of error. ${ }^{57}$ This action seems to be an exception to the usual practice of allowing a requested specific disposition in a moot appeal. ${ }^{58} \mathrm{Also}$, in spite of the questionable finality of the New York decree, that decision has been given stare decisis effect by the Supreme Court in subsquent cases. ${ }^{59}$

No instance has been discovered in which a disposition later occasioned serious injustice. ${ }^{60}$ The dissent of Mr. Justice Black in Alton v. Alton, ${ }^{61}$ how-

perior Court for King County, 1 Wash. 2d 379, 96 P. 2d 248 (1939) (writ of appeal denied), 310 U.S. 613 (1940) (vacated and remanded), 5 Wash. 2d 711, 105 P. 2d 70 (1940) (motion to vacate judgment granted, but motion to withdraw opinion denied, even if it could have been done as a practical matter. Motion to grant costs denied).

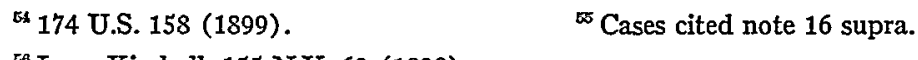

${ }^{66}$ In re Kimball, 155 N.Y. 62 (1898).

${ }^{57}$ Kimball v. Kimball, 174 U.S. 158 (1899). Apparently no further actions were attempted by the alleged widow.

${ }^{5 s}$ United States v. Munsingwear, Inc., 340 U.S. 36 (1950) (vacation will be granted on request) ; Pan American Airways Corp. v. Grace \& Co., 332 U.S. 827 (1947) (dismissal of appeal granted on mutual request). Consult Stern \& Gressman, Supreme Court Practice 342 (1950 ed.). Consult note 38 supra for discussion of the ambiguous position of the Supreme Court concerning the "duty" of the circuit courts of appeals to reverse or vacate moot appeals.

${ }^{69}$ The United States Supreme Court cites In re Kimball, 155 N.X. 62 (1898), as authority within New York in Atherton v. Atherton, 181 U.S. 155, 170 (1901); Omsted v. Omsted, 216 U.S. 386, 391 (1910).

${ }^{60}$ But see note 29 supra. 347 U.S. 610,611 (1954). 
ever, raises this specter. Mr. and Mrs. Alton were residents of Connecticut. Mrs. Alton moved to the Virgin Islands and after a six week and one day residence filed an action for divorce. Mr. Alton entered a general appearance but did not contest. The judge refused to hear the cause on the ground that the petitioner had not established domicile in spite of compliance with the statutory domiciliary requirements. The court of appeals affirmed the want of jurisdiction en banc by a divided court. ${ }^{62}$ Certiorari was granted ${ }^{63}$ and the case was argued on April 7, $1954 .{ }^{64} \mathrm{Mr}$. Alton subsequently obtained a divorce in Connecticut, and on May 17, 1954, the Court issued an order requiring the parties to show cause why the judgment should not be vacated and the cause dismissed as moot. ${ }^{65}$ On June 1,1954 , the Court ordered that " $[t]$ he judgment of the Court of Appeals is vacated and the cause is remanded to the District Court with directions to vacate its judgment and to dismiss the proceeding upon the ground that the cause is moot."66 Justice Black in his dissent declared that the Supreme Court should determine whether the petitioner was entitled to have her Virgin Islands divorce, since under Williams v. North Carolina $I I, 67$ the Connecticut divorce may not protect the petitioner from conviction for bigamy in the Virgin Islands or elsewhere.

While it appears that Justice Black's fears were groundless, a few alterations in the facts will illustrate the problem he apparently had in mind. Assume that in the divorce proceeding in the Virgin Islands, $\mathrm{H}$ had entered a special appearance contesting the court's jurisdiction. W nevertheless is granted her divorce, and $\mathrm{H}$ appeals the finding of jurisdiction to the court of appeals, which affirms, and then to the Supreme Court. $H$ then attempts to establish residence in Nevada, desiring a divorce in which his wife appears to be the guilty party. Before the Supreme Court has acted, Nevada enters a decree of absolute divorce. The Supreme Court then follows the same procedure it used in the Alton case, and orders the proceedings below to be vacated. $W$ remarries, and returns to Connecticut. That state then institutes a bigamy prosecution against her and under the doctrine of Williams v. North Carolina $I I^{68}$ overcomes the presumption of validity of the Nevada divorce by proving that $\mathrm{H}$ had not been domiciled there. Because of the Supreme

${ }^{62}$ Alton v. Alton, 207 F. 2d 667 (C.A. 3d, 1953).

${ }^{\infty}$ Alton v. Alton, 347 U.S. 911 (1954).

${ }^{\infty}$ Alton v. Alton, 347 U.S. 610,611 (1954). A serious constitutional question, the validity of the Virgin Islands divorce law making residence prima facie domicile, was raised by the Alton case. Another case involving the identical question reached the Supreme Court almost immediately. Granville-Smith v. Granville-Smith, 349 U.S. 1 (1955), held that the Virgin Islands' legislature had exceeded the powers granted by its Organic Act.

${ }^{\circ} 325$ U.S. 226 (1945). Williams was convicted of bigamy after a remarriage in North Carolina preceded by a Nevada divorce which North Carolina found to be invalid for lack of jurisdiction.

325 U.S. 226 (1945). Every state may examine another state's divorce judgments to see if jurisdiction was obtained over the parties. 
Court's disposition of the Virgin Islands decree, $W$ has been deprived of the defense of that decree, which Connecticut may have found to be valid. It is apparent that in this hypothetical situation the injustice to $\mathrm{W}$ may be considerable if the Supreme Court vacates the Virgin Islands decree. No reason can be suggested why $W$ should not have whatever res judicata benefits she can derive from the Virgin Islands decree, and accordingly the Supreme Court should dismiss the appeal rather than vacate all proceedings below. If the judgment below is consistent with the reason the case has become moot, dismissal of the appeal is desirable in order to protect the parties in case the appeal really is not moot. ${ }^{69} \mathrm{~A}$ similar situation may arise in guardianship or other proceedings involving domestic relations.

Justice Black pointed out that the proceedings in the Alton case might not be moot since if the Connecticut divorce were invalid, the parties were still married. But the Altons being residents of Connecticut, that state's decree was almost certainly valid. And in any case, the Virgin Islands divorce had not been granted. It is perhaps questionable whether the hypothetical case would be considered moot by the Supreme Court. ${ }^{70}$

\section{II}

It has been illustrated that a major problem in the appellate disposition of moot cases is the degree to which the lower court decision on the merits should be accorded res judicata effect. The order entered by the Supreme Court controls this to the extent that vacation eliminates the lower judgment and any res judicata effect. If the Supreme Court simply dismisses the appeal, presumably the decision below on the merits remains outstanding and collateral estoppel effect attaches. ${ }^{71}$

It may be categorically stated that no single rule should mechanically be applied in every case. There is a fundamental conflict between the policy of concluding litigation underlying the doctrines of res judicata and the desire not to preclude parties who have not had a full appellate review. Generalizations are necessarily difficult; the following analysis considers only the simpler illustrations of this underlying conflict.

The doctrines of res judicata may be subdivided into collateral estoppel, merger, and bar. Parties are precluded from relitigating facts in a second

\footnotetext{
${ }^{2}$ But see discussion of Acheson v. Droesse, 197 F. 2d 574 (C.A. D.C., 1952) note 38 supra.

${ }^{70}$ If both parties agree that the appeal is moot, the Supreme Court would presumably be bound since adversaries would be lacking. If $W$ were to argue that the Nevada decree was not necessarily valid, the Court might not dispose of the appeal as moot, but the Court would have to make a finding of the invalidity of the Nevada decree before it could dispose of the appeal on the merits. It is suggested that in the hypothetical situation the Supreme Court would have to dispose of the appeal as moot without making a finding on the question of the validity of the Nevada divorce.
}

${ }^{71}$ Consult Munsingwear discussion page 83 supra. 
cause of action that were actually decided in a previous suit. If the plaintiff receives a money judgment the cause of action is merged into his judgment and may not be sued on subsequently. If the defendant receives a judgment on the merits the parties are barred from relitigating the cause of action. The first is collateral estoppel, the second merger, and the third bar. ${ }^{\mathbf{2}}$

Respecting collateral estoppel, the Restatement of Judgments says: "Where a party to a judgment cannot obtain the decision of an appellate court because the matter determined against him is immaterial or moot, the judgment is not conclusive against him in a subsequent action on a different cause of action." ${ }^{.73}$ Allegheny County v. Maryland Casualty Co. ${ }^{74}$ illustrates the application of this principle. Poole Engineering Company had sold a large quantity of voting machines to the county. A taxpayer, Bassett, brought a prior suit in equity to restrain the county from paying the balance of the purchase price on the ground that the machines were defective. Poole was joined as a necessary party. After Bassett's evidence had been heard, Poole's motion to dismiss was granted, Bassett appealing from the decree ordering dismissal. Meanwhile Poole was granted a mandamus ordering the county to pay the remainder of the price and the county complied before Bassett's appeal was heard. The Court of Common Pleas for Allegheny County decided that Bassett's appeal was moot, and it was dismissed. The Pennsylvania Supreme Court affirmed.75 In the principal action the county sought payment from Maryland Casualty Company as surety for Poole, alleging that the machines were defective. Maryland (as privity with Poole) sought to use the decision of the chancellor in the Bassett case to estop the county from relitigating the question of the fitness of the machines. The Third Circuit held that because the Bassett case had become moot before the appeal was heard, no res judicata effect could attach to the chancellor's opinion. ${ }^{76}$

The authors of the Restatement have felt that for purposes of collateral estoppel the desirability of appellate review outweighs the policy of preventing relitigation of factual issues. ${ }^{77}$ The Munsingrear case suggests that in the federal courts the question turns on the disposition given the moot appeal,

72 Definitions may be found in the Restatement of Judgments. Consult $\$ \$ 45(\mathrm{a}), 46$ (a), 47 (merger); 45(b), 46(b), 48 (bar) ; 45(c), 46(c), 68 (collateral estoppel).

? Restatement of Judgments, $\S 69(2)$. In the federal courts, apparently, a party wishing to avoid collateral estoppel effects must request and obtain reversal or vacation and dismissal. United States v. Munsingwear, Inc., 340 U.S. 36 (1950). Consult discussion page 83 infra.

${ }^{73} 146$ F. 2 d 633 (C.A. 3d, 1944), cert. denied 325 U.S. 855 (1945), annotated at 157 A.L.R. 1032 (1945).

${ }^{75}$ Bassett v. Armstrong, 309 Pa. 296, 163 At1. 525 (1932).

${ }^{\text {"I }}$ It may be questioned, however, whether the county should not be collaterally estopped from relitigating the fitness of the machines because of its failure to use this defense in the mandamus proceeding.

${ }^{7}$ Consult also Scott, Collateral Estoppel by Juđgment, 56 Harv. L. Rev. 1, 9 (1942). 
although the Supreme Court will allow most all moot appeals to be reversed. ${ }^{78}$ The policy behind the Restatement's position on collateral estoppel need not necessarily control for purposes of merger and bar. The Restatement of Judgments does not adopt a position on whether merger or bar should attach in a case moot on appeal. Whereas in collateral estoppel two causes of action are involved, in merger and bar, by definition, only one cause of action is present and the question is whether the entire case should be tried anew. Two examples should suffice to illustrate that the latter situations require a different general principle.

1. Assume that $P$ owns two dwellings located near D's factory. Vibration from the factory damages both dwellings. $P$ sues for the damage to one dwelling and receives judgment. The parties compromise while an appeal is pending before the Supreme Court. In this situation the appeal is moot, but the Court should dismiss the appeal rather than vacate the proceedings. There is always the possibility that $\mathrm{P}$ will attempt to bring suit for the damage to the other dwelling. If the case had not become moot, P's second claim would have become merged into his judgment on simple principles of splitting a cause of action. ${ }^{79} \mathrm{P}$ should not be permitted to escape the force of this rule simply because mootness intervenes.

2. $P$ sues $D$ for breach of contract. $D$ has a counterclaim on the contract, but does not present it; judgment is entered for $D$ on P's claim. $P$ appeals, but while the appeal is pending the parties settle. Again the Supreme Court should dismiss the appeal rather than vacate. $\mathrm{D}$ would have been barred from bringing his counterclaim as an original action if the case had not become moot, ${ }^{80}$ and the fortuitous occurrence of mootness should not permit $D$ to correct his error.

A major consideration in the disposition of moot appeals should be, of course, that injustice be avoided in the immediate situation, and in certain cases this means that vacation rather than dismissal is the preferable decree. A prospective order to comply with a statute is a simple illustration. If the statute is repealed while an appeal is pending, quite clearly the Supreme Court should vacate so that the defendant cannot be required to perform in accordance with the repealed statute. ${ }^{81}$ Another illustration is where the mootness can be remedied by a proper amendment of the pleadings. In such cases, the Court should remand to the trial court for further proceedings. ${ }^{82}$ In some situations, the continuation of an order or judgment may hamper a person or

\footnotetext{
${ }^{78}$ But see note 18 supra.

${ }^{79}$ Szostak v. Chevrolet Motor Co., 279 Mich. 603, 273 N.W. 284 (1937).

${ }^{50}$ Federal Rules of Civil Procedure, Rule 13(a).

${ }^{81}$ United States v. Anchor Coal Co., 279 U.S. 812 (1929); New Orleans Flour Inspectors v. Glover, 160 U.S. 170 (1895), vacated 161 U.S. 101 (1896) (semble).

${ }^{82}$ South Spring Gold Co. v. Amador Gold Co., 145 U.S. 300 (1892) (semble), discussed note 24 supra.
} 
tend to bring him into disrepute. If there is a mandamus order to a public official, and the order is complied with before the appeal is heard, it probably is desirable to vacate for this reason..$^{83}$ Other situations may involve paternity or bastardy proceedings, where marriage has subsequently occurred. In such cases, the interest of the child as well as the parties in litigation must be considered.

In summarizing res judicata considerations, the Supreme Court has apparently adopted reversal of the lower judgment as the disposition for moot appeals in an effort to prevent unforeseen and undesirable effects. These effects have been of two types, collateral estoppel and the consequences of continuation of a judgment which by its very nature should be eliminated when the appeal is moot. The Supreme Court has apparently not considered the possibility of the application of merger and bar in judgments moot on appeal. There is no reason why a judgment moot on appeal should not have as much effect as is possible and just. It would seem that in order that a possible second suit be avoided if one of the parties has failed to bring a claim at the proper time, the proper procedure for the Supreme Court in disposing of the moot appeal should be to dismiss the appeal rather than to reverse or vacate. A party who feels himself unjustly prejudiced by allowing the decision on the merits to stand would then have the burden to show cause why it should be reversed or vacated. In addition, discretion should be allowed the courts in exceptional situations to refuse to apply bar and merger where the result would be injustice.

\section{III}

Theoretically, stare decisis considerations should not enter into the Supreme Court's determination of whether a moot appeal should be dismissed or whether an order to vacate should be entered. If the opinion below is officially reported, it will always remain in the volume; even if the decision is vacated, the force of the reasoning remains. ${ }^{84}$ There has never been any doubt that cases which reach a state supreme court on the merits are full authority within that state, even though they become moot on appeal to the Supreme Court. ${ }^{85}$

${ }^{83}$ Browniow v. Schwartz, 261 U.S. 216 (1923) (semble).

st Consult Granville-Smith v. Granville-Smith, 214 F. 2d 820 (C.A. 3d, 1954). The Court of Appeals for the Third Circuit which had also decided the Alton case followed the reasoning therein even though the Alton decision had been reversed and dismissed as moot by the Supreme Court. (See supra pp. 88-89.) "That decision must govern this. While individual members of the Court have not modified their views as set out in the opinions in that case, all recognize the authority of a decision rendered after due consideration by the Court en banc." Tbid.

${ }^{85}$ Natural Milk Producers Ass'n v. San Francisco, 20 Cal. 2d 101, 124 P. $2 d 25$ (1942), vacated and remanded 317 U.S. 423 (1943), prior judgment affirmed 24 Cal. 2d 122, 148 P. 2d 377 (1944) ; Kansas v. American Book Co., 65 Kan. 847, 69 Pac. 563 (1902), writ of error dismissed 193 U.S. 49 (1904), decision followed in Kansas v. Western Union Telegraph Co., 75 Kan. 609, 90 Pac. 299 (1907), and Cudahy Packing Co. v. Denton, 79 Kan. 369, 97 Pac. 439 (1909); Condon v. Maloney, 108 Tenn. 82, 65 S.W. 871 (1901), appeal dismissed 189 
The Supreme Court itself implied that it might give some stare decisis effect to a decision moot upon appeal in Posados v. Warner Barnes $\& \mathrm{Co}^{86}$

Practically, however, the form of the Supreme Court decree may in certain circumstances affect the stare decisis value of the decision on the merits as indicated by the recent case of Harris v. Battle. ${ }^{87}$ A state statute empowered the governor to seize certain public service industries if a strike deemed harmful to the public welfare were threatened. ${ }^{88} \mathrm{~A}$ union challenged the constitutionality of this provision when the governor threatened to seize a transportation company in Richmond. The Circuit Court of the City of Richmond denied the union's petition for an injunction to restrain the governor perpetually from exercising his power, holding that the statute was in conflict with neither the federal constitution nor the National Labor Relations Act. ${ }^{89}$ The governor seized the transportation system, the dispute was settled, and the governor relinquished control of the system before the union's appeal was decided by the Virginia Supreme Court of Appeals. That court held the appeal moot; it entered an order dismissing the appeal, "the effect of which is to affirm the decree of the said circuit court."90 On appeal by the union the United States Supreme Court concurred in the finding of mootness and vacated the order of the Virginia Supreme Court of Appeals, remanding for such proceedings as that court deemed appropriate. ${ }^{91}$

U.S. 64 (1903), decision followed in Darnell v. Shepard, 156 Tenn. 544, 324 S.W. 661 (1928); Little v. Bowers, 46 N.J.L. (S. Ct.) 300 (1884), writ of error dismissed 134 U.S. 547 (1890), decision followed in McCran v. Ocean Grove, 96 N.J.L. (S. Ct.) 158, 114 Atl. 15 (1921).

${ }^{88} 279$ U.S. 340, 345 (1929). "The doctrine of stare decisis does not apply with full force prior to decision in the court of last resort." (Reference was to a case moot on appeal.)

${ }^{87} 348$ U.S. 803 (1954). The Harris case concerns the only appeal to the Supreme Court in a controversy moot before reaching the highest state court. This fact in itself justifies considering the case independently of the other post-1919 state cases moot on appeal (notes 15 and 17 supra).

${ }^{\infty}$ Chapter 696 Laws of 1952, Virginia.

${ }^{80} 26$ Labor Cases ๆ 68,733.

${ }^{20}$ The full order of the court is reported in 26 Labor Cases \& 68,733 and not in the official Virginia reporter which merely states, "appeal refused." Harris v. Battle, 195 Va. Ixxxviii (1954).

n Mr. Justice Reed thought that the appeal should be dismissed for lack of jurisdiction on the authority of Norfolk \& Southern Turnpike Co. v. Virginia, 225 U.S. 264, 269 (1912). (After a state court refuses to hear an appeal for want of jurisdiction the Supreme Court will not take jurisdiction.) Since the Supreme Court found in the Harris case that there was jurisdiction to entertain the appeal, Mr. Justice Reed voted to dismiss (whether the appeal or the full proceeding is not disclosed) on the ground of mootness. The majority of the Court in the Harris case held that the case was moot and vacated and remanded the Virginia Supreme Court of Appeals' judgment on the authority of United States v. Anchor Coal Co., 279 U.S. 812 (1929) (injunction vacated when moot on appeal). The injunction in the Anchor case had been issued by a lower federal court. In the Harris case the Circuit Court of the City of Richmond, a state court, denied the requested injunction; thus there was no outmoded injunction to hamper anyone. It is believed that the Anchor Coal case is not authority for the action taken by the Supreme Court in the Harris case.

Mr. Chief Justice Warren, Mr. Justice Black, and Mr. Justice Douglas were of the opinion 
The Virginia Supreme Court of Appeals received the remanded cause on December 9, 1954 and on January 19, 1955 entered the following order: "[I]t appearing that the cause has become moot, and that there no longer exists a justiciable issue to be determined by the Court, it is adjudged and ordered by this Court that the said petition for appeal be and the same is hereby rejected and the appeal refused." (Italics added.) The matter is now considered closed by the Virginia court. ${ }^{93}$

The Harris case was moot before reaching the highest Virginia court, thus presumably there was no "case" or "controversy"94 when certiorari was granted. However, if the Munsingwear doctrine applies to cases involving federal questions moot before the highest state court, it was necessary for the union to appeal to the Supreme Court in order to preclude collateral estoppel attaching to the decision of the Circuit Court of the City of Richmond. But the Supreme Court neither mentioned the Munsingwear case nor offered any rationale for taking jurisdiction. The Supreme Court's use of the usual form of decree in cases moot after appeal from a state court was an interference with Virginia's disposition of its own moot appeals, and certainly can be construed as a rebuff to the Virginia court. ${ }^{95}$

The commentator in Labor Cases in commenting on the Harris case states:

Inasmuch as the case had become moot, the state supreme court, on appeal from a trial court decision which sustained the validity of the state law and denied an injunction, should not have handed down a decision the effect of which was to affirm the trial court's decree. For that reason, the U.S. Supreme Court vacates the state supreme court's judgment and remands the case to that court for appropriate action. ${ }^{96}$ [Italics added.]

that the case was not moot, but gave no grounds for their opinion. It is suggested that possibly the dissenters were confusing the "continuing controversy" concept (Consult Southern Pacific Terminal Co. v. ICC, 219 U.S. 498 [1911]), in which situation the Supreme Court does not dismiss the action as moot, with the "public expedience" type of dispute which, in spite of the public interest involved, the Supreme Court has consistently refused to decide where the controversy is moot. Consult Amalgamated Ass'n of S.E.R. \& M.C.E. of A. v. Wisconsin Employment Relations Board, 340 U.S. 416, 418 (1951) ; People ex rel. Wallace v. Labrenz, 411 IIl. 618, 104 N.E. 2d 769 (1952), cert. denied 344 U.S. 824 (1952).

${ }^{93}$ Copy of the Virginia Court of Appeals decree submitted by the Clerk of Court, October 27, 1955 .

${ }^{2}$ Letter of the Clerk of Court, October 27, 1955.

of U.S. Const. Art. 3, $\$ 2$. Consult note 4 supra.

${ }^{\infty 5}$ The customary disposition in cases moot on appeal because of the lapse of time (e.g., the Harris case) in the Virginia Supreme Court of Appeals, is appeal dismissed. Hankins v. Virginia Beach, 182 Va. 642, 644, 29 S.E. $2 d$ 831, 832 (1944); Hamer v. Commonwealth, 107 Va. 636, 637, 59 S.E. 400 (1907) ; Franklin v. Peers, 95 Va. 602, 603, 29 S.E. 321 (1898).

${ }^{00} 26$ Labor Cases 968,733 . The decision by the Richmond court appears to be in direct conflict with the Supreme Court's opinion in Amalgamated Ass'n S.E.R. \& M.C.E. of A. v. Wisconsin Employment Relation Board, 340 U.S. 383 (1951), which decided that the National Labor Relations Act, as amended by the Labor-Management Relations Act of 1947, $\$ 206-10$, providing for emergency situations, specifically public utilities labor disputes, had pre-empted the field from the states. 
It might be inferred that the Supreme Court wished to inform the Virginia courts that the lower decision was incorrect and should not be followed, thus indirectly indicating that the Richmond court decision should have no stare decisis effect in other cases arising in the Virginia courts. But then the majority of the Supreme Court apparently decided on the merits a case they held to be moot.

\section{IV}

Conclusions and generalizations are necessarily difficult to make. Certainly, a universally applicable rule of disposition, as it appears the Supreme Court has developed, may lead to injustice in some instances. The decision of the Supreme Court in Harris v. Battle may represent a rigid application of the usual rule of vacation. If this is all the case represents, it nevertheless will probably be interpreted as a decision on the merits in a moot case.

The position adopted by the Supreme Court in the Munsingwear case apparently is that collateral estoppel will attach in an unreversed judgment moot on appeal. It might be argued that where the mootness issue is carried to the highest court, collateral estoppel should not attach irrespective of the mode of disposition. Because of this fear of collateral estoppel, however, judgments have since been always vacated or reversed. This may mean that merger and bar effects are not now possible in judgments moot on appeal. The rule of the Munsingwear case has led the Supreme Court further than it realized at the time. Considerations of fairness to the immediate parties should govern disposition of a moot appeal. In the absence of factors recommending reversal or vacation of the lower decree, it is suggested that all moot appeals to the Supreme Court ought to be dismissed so as to gain whatever res judicata benefits there may be. Stare decisis is not a proper subject for consideration in the selection of a method of disposition.

\section{CONSIDERATION FOR THE EMPLOYER'S PROMISE OF A VOLUNTARY PENSION PLAN}

There are two basic types of pension plan: those voluntarily adopted by the employer, and those which are the product of collective bargaining. The courts have had some analytical difficulty with voluntary plans. ${ }^{1}$ The central

\footnotetext{
"The phrase "voluntary pension plan" can be confusing. Its usual meaning is "voluntarily adopted by the employer"; however it is also used where the employee has the option of contributing or not contributing to the plan. Throughout this comment, unless otherwise indicated, "voluntary pension plan" means a plan voluntarily adopted by the employer and not a plan which is the result of collective bargaining.

It should be added that while current interest is centered on collective bargaining and executive pension plans, this comment is concerned solely with the problem of consideration for the employer's promise of a pension plan. Discussion of collective bargaining and executive pension plans is accordingly limited to occasional comments bearing on the consideration problem generally.
} 